\title{
Evaluation of the Opinions of the First, Second and Third Term Medical Students About Problem Based Learning Sessions in Bezmialem Vakıf University
}

\section{Bezmialem Vakıf Üniversitesi Tıp Fakültesi 1. 2. ve 3. Sınıf Öğrencilerinin Probleme Dayalı Öğrenim Oturumları Hakkındaki Görüşlerinin Değerlendirilmesi}

(D) Nurten Seda KORKMAZ1 ${ }^{1}$ ib Semra ÖZÇELIKK²

1Bezmialem Vakıf University Faculty of Medicine, $5^{\text {th }}$ grade Stj Dr., İstanbul, Turkey

${ }^{2}$ Bezmialem Vakıf University Faculty of Medicine, Department of Medical Education and Informatics, İstanbul, Turkey

\section{ABSTRACT}

Objective: Problem-based learning (PBL) is a student-centered small group study and active learning method. It aims to provide students with the skills of self-learning, learning to learn, and solving realworld problems and is used as a learning method in many medical faculties. In this study, it was aimed to examine and evaluate the perceptions and opinions of Bezmialem Vakif University Faculty of Medicine students about PBL applications and all processes.

Methods: For this purpose, a questionnaire consisting of 16 questions was prepared and applied to first, second and third term students in Bezmialem Vakıf University Faculty of Medicine. In this questionnaire, students' perceptions and opinions were evaluated with a five-point Likert scale and an open-ended question.

Results: According to the results, overall satisfaction was found to be 3.67 on average. These ratios were; 3.85 in the first term students, 3.54 in the second term students, and 3.66 in third term students. As a result, the highest satisfaction was achieved in the proposition "PBL participants are always respectful to the group" with a score of 4.19. The proposition "PBL trainers help to discuss problems in every way" was found to get the lowest score (3.57). The other lowest score (3.59) was achieved in the prosposition "Everyone comes prepared for the second session in PBL sessions".

\section{ÖZ}

Amaç: Probleme dayalı öğrenme (PDÖ), bir yönlendirici eşliğinde 6-8 öğrenciyle yapılan, öğrenci merkezli küçük grup çalışması ve aktif öğrenme yöntemidir. Öğrencilere kendi kendine öğrenme, öğrenmeyi öğrenme, gerçek dünyada yaşanabilecek problemleri çözme becerilerini kazandırmayı hedefler ve birçok tıp fakültesinde öğrenme yöntemi olarak kullanılmaktadır. Fakültemizde, her dönemde en az bir kez, PDÖ oturumları uygulanmakta ve oturumlarla ilgili düzenli geribildirimler alınmaktadır. Bu çalışmada ise, Bezmialem Vakıf Üniversitesi Tıp Fakültesi öğrencilerinin PDÖ uygulamaları ve süreçleri ile ilgili algı ve görüşlerinin incelenmesi ve değerlendirilmesi amaçlanmıştır.

Yöntemler: Bu amaçla Bezmialem Vakıf Üniversitesi Tıp Fakültesi Dönem I, II ve III öğrencileri için literatürden faydalanılarak, 16 sorudan oluşan bir anket hazırlanmış ve öğrencilere uygulanmıştır. $\mathrm{Bu}$ ankette öğrencilerin algı ve görüşleri beş puanlık likert ölçeği ve açık uçlu bir soru ile değerlendirilmiştir.

Bulgular: Anket sonuçlarına göre genel memnuniyet ortalama 3,67 olarak bulunmuştur. Bu oranlar; Dönem I'de 3,85, Dönem II'de 3,54, Dönem III'te 3,66 olarak belirlenmiştir. Anket sonucunda, en yüksek memnuniyet "PDÖ katılımcıları her zaman gruba saygılıdır" maddesi 4,19 puan ile en yüksek puanı almıştır. "PDÖ eğitmenleri sorunları her yönden tartışmaya yardımcı oluyor" maddesi ise 3,57

Address for Correspondence: Semra ÖZÇELIK, Bezmialem Vakıf University Faculty of Medicine, Department of Medical Education and Informatics, İstanbul, Turkey

E-mail: semraozcelik@bezmialem.edu.tr ORCID ID: orcid.org/0000-0001-9237-6723

Cite this article as: Korkmaz NS, Özçelik S. Evaluation of the Opinions of the First, Second and Third Term Medical Students About Problem Based Learning Sessions in Bezmialem Vakıf University. Bezmialem Science 2020;8(2):144-9. 
Conclusion: With these data, accurate decisions can be made about which steps should be considered in our practices and the aspects that need to be improved. Our goal is to organize PBL sessions in each committee in the preclinical term.

Keywords: Problem-based learning, PBL, medical education, likert scale puan ile en düşük puanı almıştır. Diğer 3,59 memnuniyet puanıyla en düşük olan madde ise "PDÖ oturumlarında 2. oturuma herkes hazırlıklı gelmektedir” maddesidir.

Sonuç: $\mathrm{Bu}$ verilerle, uygulamalarımızda hangi aşamalara dikkat edilmesi gerektiği ve iyileştirilmesi gereken yönler hakkında isabetli kararlar verilebilir. PDÖ oturumlarının öğrencilerin öğrenmesine katkıda bulunduğu açıktır. Henüz PDÖ oturumlarını kısıtlı sayıda uygulayabilmekteyiz. Ancak hedefimiz preklinik dönemde her kurulda PDÖ oturumları düzenlemektir.

Anahtar Sözcükler: Probleme dayalı öğrenme, PDÖ, tıp eğitimi, likert ölçeği

\section{Introduction}

Problem-based learning (PBL) approaches have a long history based on John Dewey's work explaining the relationship between learning by trying and doing and education. PBL is therefore part of the educational tradition where the importance of meaningful and experienced learning is emphasized. PBL has inspired from different theoretical approaches about learning. Although these approaches have different theoretical roots, all emphasize that learning is an active process and that gaining experience is an important part of the learning process. PBL also facilitates learning as a student-centered and interactive activity $(1,2)$.

A problem in PBL scenarios needs to be based on reality, adapted to the student's preliminary knowledge level, able to involve students in discussions, provide identification of appropriate learning topics, encourage self-learning, and be interesting and relevant (1).

As an alternative approach to teaching and learning, PBL has become an increasingly popular practice and is now frequently used in almost all levels and areas of Education. There are some common goals in the problem-based curriculum. According to Hmelo-Silver, these goals for students can be listed as: Building a comprehensive and flexible knowledge base, developing effective problem solving and upper cognitive skills, self-management, developing lifelong learning skills, becoming effective collaborators and motivating oneself to learn (3). Basically, the goal of all learning curricula is to enable students to build a comprehensive and flexible knowledge base.

In PBL, the development of relevant competencies includes the ability to implement appropriate metacognitive and reasoning strategies. Metacognitive skills are often conceptualized as an interrelated set of competencies for learning and thinking, and include many of the skills needed for critical thinking, problemsolving, and decision-making. The development of metacognitive skills is a process by which students learn to learn (3).

Another important goal in PBL is taking responsibility by students for their own learning processes. It is stated that this responsibility taken by students can be used to improve content knowledge, problem solving, communication and critical thinking skills. In addition, there are studies showing that students who study with
PBL are generally more successful at producing solutions than groups trained with other methods $(1,3)$.

Being an effective collaborator means knowing how to work as part of a team. In PBL, students collaborate in small groups. The benefits of small group cooperation have been widely discussed in the PBL literature (1). According to researches, small group study creates a platform for the development of friendships between students, establishes closer contact and communication between the instructors and students, allows students to be diligent in their studies and complies with the deadline agreed by the group for the work and based on collaboration, it encourages students in small groups to establish a knowledge base (1). The aim of PBL is to genuinely motivate students and make them work on a task motivated by their interest in learning rather than exam and external motivations (3).

In the pre-clinical term from 2012 to the present day, PBL sessions are held at least once a year in each class in BVU Medical Faculty. The sessions take place in the training program, which will be in the committees recommended by the PBL Commission. It is implemented in three sessions in a one-week term immediately at the beginning of the committees. PBL routers take courses organized by the Department of Medical Education and Informatics, participate as monitors and then are assigned as routers. It is ensured that the scenarios are integrated with the subjects of the committees in which they are located, that they are interesting, curious in line with the learning goals and that they are also in the structure that addresses the biopsychosocial environment of the patient. Scenarios that have received the PBL Commission's approval are being implemented. Informative meeting is held with Term I students before the start of the PBL sessions, and the objectives, method of implementation, measurement and evaluation issues are explained to students. Students are divided into groups of 8-10 people, small group study rooms are prepared for the sessions, and PBL sessions are implemented in accordance with scenarios set out with a problem and the accompanying questions. Interactive methods such as brainstorming and discussions are implemented in the sessions, and the participation of all individuals in the group in the discussions is encouraged by the routers. There are structured assessment forms that evaluate student's participation and contributions during the sessions. Students are evaluated 
by router lecturers through these forms. In addition, the grades taken from the multiple choice exam at the end of the sessions are evaluated and their impact value is $10 \%$ of the committee. At the end of the sessions, feedback is received from both lecturers and students and they are asked to express their views on the issues such as the session and scenario. Changes to be made for the next applications in line with the recommendations will be decided by the commission. Our training program does not consist entirely of PBL sessions. The integrated system is applied in the preclinical term. Although there are application targets in every committee, PBL can be applied in some committees.

Many valuable studies of educational science agree that PBL is an important learning method with many positive aspects. The aim of this study is to evaluate this method in our faculty with the eyes of the students and to obtain their opinions.

\section{Methods}

A 16-question questionna was prepared for the term I, II and III students to obtain their views on the PBL practices included in their curriculum in the 2017-2018 academic year. Prior to the study, an application was made to Bezmialem Foundation University Non-Interventional Ethics Committee and the approval was obtained with the decision number 10/146 on 16.05.2017. A total of 354 students filled out the survey and the data were collected. The survey questions were prepared using the process in our faculty, situations and similar literature. The survey questions mainly contained three key elements: 1 . Awareness before PBL sessions, 2.Process during sessions and 3. Questions about the situation after the sessions and about activities and practices performed. Proposition 1 contains the situation and thoughts before the sessions, propositions 2-11 during the sessions, and propositions 12-16 after the sessions. The first question in the survey was answered as "Yes" or "No". The answers given to the other 14 questions were classified according to the quintuple rating system (5: absolutely agree, 4: agree, 3: uncertain, 2: disagree, 1: strongly disagree). The last $\left(16^{\text {th }}\right)$ question was asked to students to make a general evaluation and a score between 1-5 was given. Prior to the study, approval was obtained from the BVU Non-Interventional Clinical Studies Ethics Committee. The population of term I students was 133 and 34 (25.6\%) of them participated in the survey. The population of term II students was 94 and 37 (39.4\%) of them participated in the survey. The population of term III students was 127 and $89(70.1 \%)$ of them participated in the survey. A total of 354 students were given survey forms, but 160 (45.19\%) answered the survey.

\section{Statistical Analysis}

All statistical analyses were conducted with IBM SPSS Statistics 21.0 program at $\alpha=0.05$ significance level and $85 \%$ confidence range.

\section{Results}

A total of 160 students answered the survey by agreeing to participate in the study. Of these, 34 were term I students, 37 were term II students, and 89 were term III students. Of those who filled out the survey, 94 were female and 65 were male; while one did not answer by leaving it blank or skipping without marking. Looking at the age distribution; 54 students did not answer, while others stated that they were in the 18-26 age range. Responses to the survey and their rates are presented in Table 1. Twenty four of 160 students (15.0\%) answered "No", while 119 $(74.4 \%)$ answered "Yes" to the question "Did you know about the PBL sessions in advance?".

There was no age-related comparison in terms of overall satisfaction as the students were in similar age groups. However, gender comparison was made and no significant differences were found ( $\mathrm{p} \geq 0.05$ ) (Table 1$)$.

According to the survey results, the overall satisfaction rate of the $16^{\text {th }}$ question was 3.67 on average. These rates were determined as 3.85 in term I, 3.54 in term II and 3.66 in term III students. Four $(2.4 \%)$ of the students answered as "Not satisfied at all", $7(4.4 \%)$ as "Not Satisfied", $48(30.4 \%)$ as "Uncertain", 77 (48.7\%) as "Satisfied" and $22(13.9 \%)$ as "Very satisfied".

There was also no significant difference between term I, II and III in terms of PBL satisfaction rates $(\mathrm{P} \geq 0.05)$ (Table 2).

In the evaluation of the findings, the ratio of the students who chose the "Agree" and "Absolutely agree" categories to the study group was calculated and accepted as the student level with positive opinion, in addition to the average scores calculated for each item. "Disagree" and "Strongly disagree" answers were also rated as negative views. The "Uncertain" answer was not taken as a positive or negative opinion.

In this case, as the highest average, 134 students (83.7\%) expressed a positive opinion on the proposition "Participants in PBL sessions always treat the group with respect", while 9 students (5.7\%) expressed a negative opinion and the average $\overline{\mathrm{x}}$ was determined as 4.19 with the "Uncertain" responses. As the lowest average, 94 students $(59.5 \%)$ expressed a positive opinion on the proposition "PBL session routers help to discuss

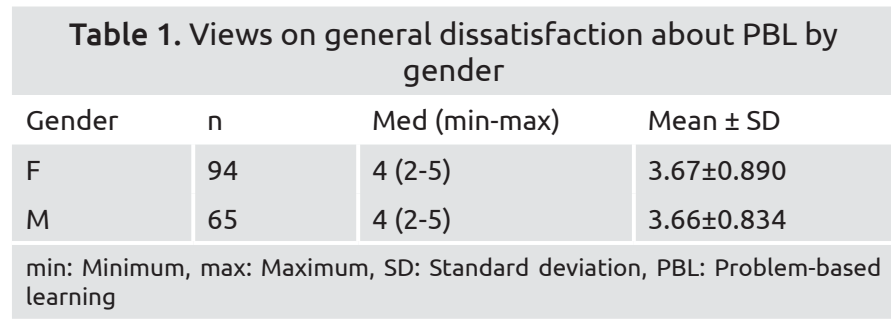

Table 2. Views on general dissatisfaction about PBL by term

\begin{tabular}{|l|l|l|l|}
\hline Term & $n$ & Med (min - max) & Mean \pm SD \\
\hline 1 & 33 & $4(2-5)$ & $3.85 \pm 0.795$ \\
\hline 2 & 37 & $4(2-5)$ & $3.54 \pm 0.988$ \\
\hline 3 & 88 & $4(2-5)$ & $3.66 \pm 0.828$ \\
\hline
\end{tabular}

SD: Standar deviation, min: Minimum, max: Maximum, PBL: Problem-based learning 
all aspects of the issues", while 26 students (16.5\%) expressed a negative opinion, and the average $\overline{\mathrm{x}}$ was determined as 3.57 with the "Uncertain" responses. The answers to all questions and their rates are given in the Table (Table 3).

Some of the students wrote answer and expressed their views for the open-ended question "Is there anything else you want to add?". Some of these were: "The efficiency I got from PBL sessions varies according to the session router and the students involved", "The knowledge gained through the PBL sessions has had a positive impact on my learning life", "While some of the session routers were willing, some were unwilling and not motivating", and "The evaluations of the routers were not objective".

\section{Discussion}

It is suggested that PBL is much more motivating in solving theoretical or practical problems than a traditional flexible learning process. However, problems should be applied in a motivating and productive way that suits the students' existing knowledge. In other words, the character of the problem should

Table 3. Student views on before, during and after Problem-based Learning sessions

Proposition

1. Sufficient information about PBL is given before PBL sessions are held ( $N=159 ; \bar{x}=3.60$ )

2. Everyone is prepared for the second session in the $\mathrm{PBL}$ sessions $(\mathrm{N}=160$; $\overline{\mathbf{x}}=3.59$ )

3. The classes where PBL sessions are held meet our needs $(\mathrm{N}=157 ; \overline{\mathrm{x}}=3.79)$

4. $P B L$ sessions are held with an ideal number of students $(\mathrm{N}=160 ; \overline{\mathrm{x}}=4.03$ )

5. PBL session routers help to discuss all aspects of issues $(\mathrm{N}=158 ; \overline{\mathrm{x}}=3.57)$

6. In PBL sessions, participants always treat the group with respect $(\mathrm{N}=160$; $\overline{\mathrm{x}}=4.19$ )

7. $I$ express myself adequately in PBL environments and/or group works ( $N=158 ; \bar{x}=3.83$ )

8. Discussions in PBL sessions have a positive impact on my knowledge ( $N=159 ; \bar{x}=3.91)$

9. I contribute to the group in achieving the learning goals ( $N=160 ; \bar{x}=4.00)$

10. I can easily convey what I have learned after independent study (N=158, 42.5 $\overline{\mathbf{x}}=3.88$ )

11. Session routers are prepared and willing ( $N=160, \bar{x}=3.68)$

12. PBL sessions have had a positive impact on my communication skills ( $N=157 ; \bar{x}=3.61)$

13. I am happy to achieve the learning goals determined in the sessions by investigating rather than getting them as preset information ( $N=159, \bar{x}=3.72)$

14. I am satisfied with the attitude of the faculty members who lead the session ( $N=160 ; \bar{x}=3.90)$

\begin{tabular}{|c|c|c|c|c|c|c|c|c|c|c|c|}
\hline \multirow{2}{*}{\multicolumn{2}{|c|}{$\begin{array}{l}\text { Strongly disagree } \\
\text { Number \% }\end{array}$}} & \multirow{2}{*}{\multicolumn{2}{|c|}{$\begin{array}{l}\text { Disagree } \\
\text { Number \% }\end{array}$}} & \multirow{2}{*}{\multicolumn{2}{|c|}{$\begin{array}{l}\text { Uncertain } \\
\text { Number \% }\end{array}$}} & \multirow{2}{*}{\multicolumn{2}{|c|}{$\begin{array}{l}\text { Agree } \\
\text { Number \% }\end{array}$}} & \multirow{2}{*}{\multicolumn{2}{|c|}{$\begin{array}{l}\text { Strongly agree } \\
\text { Number \% }\end{array}$}} & \multirow{2}{*}{\multicolumn{2}{|c|}{$\begin{array}{l}\text { Total } \\
\text { Number \% }\end{array}$}} \\
\hline & & & & & & & & & & & \\
\hline 6 & 3.8 & & 8.8 & 51 & 32.1 & 54 & 34.0 & 34 & 21.3 & 159 & 100.0 \\
\hline 3 & 1.9 & 15 & 9.4 & 51 & 31.9 & 66 & 41.2 & 25 & 15.6 & 160 & 100.0 \\
\hline 1 & 0.6 & 28 & 17.8 & 21 & 13.4 & 60 & 38.3 & 47 & 29.9 & 157 & 100.0 \\
\hline 3 & 1.9 & 11 & 6.9 & 25 & 15.6 & 60 & 37.5 & 61 & 38.1 & 160 & 100.0 \\
\hline 6 & 3.8 & 20 & 12.7 & 38 & 24.1 & 66 & 41.7 & 28 & 17.7 & 158 & 100.0 \\
\hline 3 & 1.9 & 6 & 3.8 & 17 & 10.6 & 65 & 40.6 & 69 & 43.1 & 160 & 100.0 \\
\hline 7 & 4.4 & 11 & 7.0 & 24 & 15.2 & 76 & 48.1 & 40 & 25.3 & 158 & 100.0 \\
\hline 5 & 3.1 & 7 & 4.4 & 31 & 19.6 & 70 & 44.0 & 46 & 28.9 & 159 & 100.0 \\
\hline 4 & 2.5 & 5 & 3.1 & 29 & 18.1 & 71 & 44.4 & 51 & 31.9 & 160 & 100.0 \\
\hline 4 & 2.5 & 9 & 5.7 & 29 & 18.4 & 76 & 48.1 & 40 & 25.3 & 158 & 100.0 \\
\hline 4 & 2.5 & 14 & 8.8 & 42 & 26.2 & 69 & 43.1 & 31 & 19.4 & 160 & 100.0 \\
\hline 7 & 4.5 & 10 & 6.4 & 42 & 26.7 & 76 & 48.4 & 22 & 14.0 & 157 & 100.0 \\
\hline 6 & 3.7 & 13 & 8.2 & 40 & 25.2 & 61 & 38.4 & 39 & 24.5 & 159 & 100.0 \\
\hline 4 & 2.5 & 5 & 3.1 & 36 & 22.5 & 73 & 45.6 & 42 & 26.3 & 160 & 100.0 \\
\hline
\end{tabular}

PBL: Problem-based learning 
be able to positively influence the motivation of students to learn in PBL curricula (1).

As there are medical faculties in our country that carry out all education with PBL method, there are also models that are applied with a scenario within the committees as applied in our faculty. In a 2008 study, it was reported that PBL sessions were held in nearly half of the medical schools providing education in our country(4). However, it is a fact that there may be differences in this proportion with new medical schools, which are rapidly increasing in time today. Some new faculties have such applications due to the importance of interactive education and the appropriateness of student numbers, while some have canceled PBL due to high number of students. In the study conducted by Musal et al. at Dokuz Eylül University Faculty of Medicine (5), student opinions on the effectiveness of PBL were taken and the average scores were reported to be between 3.694.27 (maximum 5). Our average value of 3.67 was slightly lower than the value of that faculty, which applied PBL throughout its education, but it showed conformity.

Musal et al. contributed much to implementation of PBL in our country with their publications about processes of PBL programs and the role of router lecturers (6-8). They detailed how all phases of implementation should be planned, implemented and evaluated and they provided ease of application for other faculties. PBL applications in BVU Medical Faculty are also carried out in three sessions in one week term, in groups of 10 students, by the trained lecturers and students. In the survey we applied in the study, the proposition "PBL session routers help to discuss all aspects of the issues" was evaluated with average score of 3.57 , the proposition "Session routers are prepared and willing" with average score of 3.68, and the proposition "I am satisfied with the attitude and attitude of the session lecturers" with average score of 3.90. In a PBL session, the router is inherently important. However, students who are used to classroom lessons want to get more information from the router and may feel that they are not being adequately supported. The fact that the majority of the answers to the open-ended question were related to routers also underlined the importance of routing in PBL.

Velipaşaoğlu and Musal completed scale development studies related to PBL process, functioning and achievements. By using this detailed scale, the studies will be more comprehensive and useful in measuring the efficiency of PBL (9).

In the study where student opinions were taken about PBL sessions at On Dokuz Mayis University, it was reported that the overall average of scores given in feedback for PBL was $8.06 \pm$ $1.0(6-10)$ out of 10 and the overall average of scores given for communication and discussion was $4.59 \pm 0.6$ out of 5 (10). In the survey we applied, 116 students $(73.4 \%)$ gave positive views to the proposition "I express myself adequately in PBL environments and/or group studies" and $\overline{\mathrm{x}}$ was determined as 3.83; while 116 students (72.9\%) gave positive views to the proposition "Discussions in PBL sessions affect my knowledge positively" and the average $\bar{x}$ was 3.91. One hundred twenty one students $(76.3 \%)$ gave positive views to the proposition "I contribute to the group in achieving the learning goals" and $\overline{\mathrm{x}}$ was determined as 4.0 . One hundred and sixteen students $(73.4 \%)$ gave positive views to the proposition "I can easily convey what I have learned after independent study" and $\overline{\mathrm{x}}$ was determined as 3.88 . Ninety eight students $(62.4 \%)$ gave positive views to the proposition "PBL sessions affected my communication skills positively", while $17(10.9 \%)$ students gave negative views and $\overline{\mathrm{x}}$ was determined as 3.61 with "uncertain" answers. Compared with the findings of that study, we found lower rates of positive opinions.

Alimoğlu et al. investigated the satisfaction of term I students in Akdeniz University Medical Faculty on PBL applications. It was stated that PBL contributed to students in self-learning, establishing connections between basic sciences and clinical sciences, and lifelong learning. In addition, the number of those who thought that it contributed to the development of basic skills such as communication with the patient, being able to approach the patient as a biopsychosocial whole, reasoning in the face of the problem, problem solving and decision making were found to be high. In their study, they found that $44.4 \%$ of the students were satisfied with PBL, 27.8\% were dissatisfied and $27.8 \%$ were uncertain about it (11). In our survey, 99 BVU students gave positive view and $11 \mathrm{BVU}$ students (6.9\%) gave negative view to the question "What is your overall satisfaction with PBL sessions?", while 48 BVU students (30.4\%) were uncertain about it. The average $\bar{x}$ value was determined as 3.67. It was observed that the rates of positive responses of BVU medical faculty students were slightly higher.

Demirören and Demirel (12) investigated the views of term II students in Ankara University Medical Faculty on the advantages and limitations of PBL. As a result, the students found PBL superior to traditional method and they found PBL environment motivating and enhancing universal competencies (problem solving, analysis and synthesis, communication skills). Integration of basic and clinical sciences, development of a biopsychosocial approach to human beings, and effective and motivating learning in small groups were mentioned as the most supported features of PBL. However, it was noted that students had difficulty in adapting to PBL, that they remained concerned about becoming independent learners, and that there were negative issues arising from PBL orientation processes (12).

In the survey we applied, 100 students (62.9\%) expressed a positive opinion on the proposition "I am happy to achieve the learning goals determined in the sessions by investigating rather than getting them as preset information", while 19 students $(12.0 \%)$ expressed a negative opinion and the average $\overline{\mathrm{x}}$ was determined as 3.72 with the uncertain responses. High ratio and average values of positive responses suggested that the students were not forced into the PBL integration process and that their concerns about becoming independent learners were not high.

Gürpınar et al. included the views of router lecturers on the PBL program in their study. Of the lecturers, $70.2 \%$ stated that PBL applications were generally beneficial for the student and $56.5 \%$ answered "Yes" to the question "Are you satisfied with 
PBL" (13). In their study in 2016, Musal (14) found that the scores given by router lecturers to the gains of the PBL method ranged from 3.3 to 4.7 out of 5 . The highest scores were given to the improvement of communication skills (14). In our study, the lack of any questionnaire applied to router lecturers constituted the limitation of this study.

In a study that examined the change in the performance of students in PBL sessions over the years, the increase in performance scores obtained from term I to term III was evaluated as a positive finding. When the average score for each parameter was evaluated, it was determined that the scores of term III students were higher than term I students (15). In our study, performance evaluation was not performed between terms, but there was no significant difference in the satisfaction rates of PBL sessions.

\section{Conclusion}

As a result, the PBL has been formed with quite different pedagogical approaches. Unlike traditional learning, it actively centers the student. PBL imparts self-directed learning, finding learning goals, accessing and finding information, time management, question-asking behavior, critical thinking, and comprehensive self-monitoring and evaluation skills (16). These positive aspects bring PBL practices to the fore in medical education. It has been determined that the PBL sessions that we have implemented in some committees during the pre-clinical process, which consists of system-based committees, constitute an efficient training process in our faculty where integrated system is applied. We aim to apply this interactive method to every committee.

\section{Ethics}

Ethics Committee Approval: Prior to the study, an application was made to Bezmialem Foundation University NonInterventional Ethics Committee and the approval was obtained with the decision number 10/146 on 16.05.2017.

Informed Consent: Survey study.

Peer-review: Externally peer reviewed.

\section{Authorship Contributions}

Concept: N.S.K., S.Ö., Design: N.S.K., S.Ö., Data Collection or Processing: N.S.K., S.Ö., Analysis or Interpretation: N.S.K., S.Ö., Literature Search: N.S.K., S.Ö., Writing: N.S.K., S.Ö.

Conflict of Interest: No conflict of interest was declared by the authors.

Financial Disclosure: The authors declared that this study received no financial support.

\section{References}

1. Schmidt GH, Rotgans JI, Yew EHJ. The process of problem-based learning: what works and why, Medical Education 2011;45:792-806.
2. Scott, B. Principles of Problem and Project Based Learning. Aalborg University.2000.

3. Hmelo-Silver CE. Problem-Based Learning: what and how do students learn? Educational Psychology Review 2004;16:235-66.

4. Musal B, Taşkıran HC, Özan S. Türkiye'de tıp fakültelerinde Probleme Dayalı Öğrenim yöntemi kullanımı. Tıp Eğitimi Dünyası 2008;28:1-7.

5. Musal B, Taşkıran C, Kelson A. Opinions of tutors and students about effectiveness of PBL in Dokuz Eylül Üniversitesi School of Medicine. Med Educ 2003;8:16.

6. Musal B, Akalın E, Kılıç O, Esen A, Alıcı E. Dokuz Eylül Üniversitesi Tıp Fakültesi Probleme Dayalı Öğretim programı, süreçleri ve eğitim yönlendiricilerinin rolü. Tıp Eğitimi Dünyası 2002;9:39-49.

7. Berna Musal, Yucel Gursel, H Cahit Taskiran, Sema Ozan, Arif Tuna. Perceptions of first and third year medical students on selfstudy and reporting processes of problem-based learning BMC Med Educ 2004;4:16.

8. Erol Gurpinar, Berna Musal, Gazanfer Aksakoglu, Reyhan Ucku. Comparison of knowledge scores of medical students in problembased learning and traditional curriculum on public health topics. BMC Med Educ. 2005;5:7.

9. Velipaşaoğlu S, Musal B. Probleme Dayalı Öğrenim süreci, işleyişi ve kazanımlarına ilişkin ölçek geliştirme çalışmaları. Tıp Eğitimi Dünyası 2017;48:5-28.

10. Dikici M, Yalçın M, Büyükakkuş A, Özbenli T, Yarış F. Ondokuz Mayıs Üniversitesi Tip Fakültesi öğrencilerinin mesleki beceri laboratuarı, Probleme Dayalı Öğrenme oturumları ve sunumlar hakkındaki görüşleri. Tıp Eğitimi Dünyası 2004;16:21-4.

11. Alimoğlu MK, Gürpınar E, Şenol Y, Çubukçu S, Aktekin M. Akdeniz Üniversitesi Tıp Fakültesi Dönem I öğrencilerinin Probleme Dayalı Öğrenim uygulamaları konusundaki memnuniyetleri. Tıp Eğitimi Dünyası 2004;14:8-14.

12. Demirören M, Demirel M. Ankara Üniversitesi Tıp Fakültesi Dönem 2 öğrencilerinin PDÖ uygulamalarının üstünlük ve sınırlılıklarına ilişkin görüşleri. Tıp Eğitimi Dünyası 2006;23:33-40.

13. Gürpınar E, Akyıldız F, Özbudak Ö, Şenol Y. Akdeniz Üniversitesi Tıp Fakültesinde uygulanan Probleme Dayalı Öğrenimin eğitim yönlendiricileri tarafından değerlendirilmesi. Tıp Eğitimi Dünyası 2005;20:46-52.

14. Musal B. Dokuz Eylül Üniversitesi Tip Fakültesi program değerlendirme çalışmaları kapsaminda eğitim yönlendiricilerinin PDÖ programı konusundaki görüşleri. Tıp Eğitimi Dünyası. 2016;46:28-34.

15. Karademir S, Özan S, Gürsel Y, Musal B. Dokuz Eylül Üniversitesi Tip Fakültesi öğrencilerinin Probleme Dayalı Öğrenim oturumlarındaki performanslarının yıllar içerisindeki değişimi. Tıp Eğitimi Dünyası 2005;19:29-33.

16. Musal B. Tip eğitiminde program modelleri. Sayek İ, editor. Tip Eğiticisi El Kitabı. 1. baskı, Ankara Güneş Tıp Kitabevleri, 2015. p.43-54. 